\title{
橈骨遠位端骨折掌側ロッキングプレート 固定術後の長母指屈筋腱断裂
}

\author{
三 原 惊 史* 村 松 慶 一* 橋 本 貴 弘* 富 永 康 弘* \\ 瀬 戸 信一朗*田口敏 彦* 岩 永 隆 太**
}

【目的】橈骨遠位端骨折に対するロッキングプレート固定術後の長母指屈筋腱（FPL）断裂は，重大な 合併症である。今回, FPL の再建術施行例ついて検討した.【症例と結果】症例は 3 例（男 1, 女 2) で,

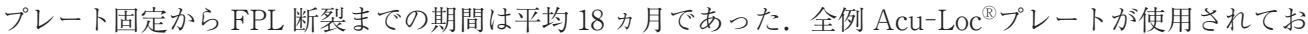
り，単純 X線にて橈骨掌側縁よりも，掌側にプレートが突出して固定されていた．診断が遅れた高齢者 の 2 例に環指浅指屈筋腱の腱移行術，1例に長掌筋の腱移植術が施行された。腱移行例は自動運動が困難 で Quick DASH score は腱移行術例で平均 49.2, 腱移植術例で 17.5 であった.【考察】FPL の断裂はプ レートの種類，設置位置，抜釷などで回避される，再建方法は，FPL 断裂を早期に診断し，腱移行術よ りも腱移植術を第一選択とすべきと考える。

Key words : distal radius fracture（橈骨遠位端骨折），flexor pollicis longus muscle tendon（長母指屈筋 腱), tendon transfer (腱移行術), tendon graft（腱移植術）

は じめに

橈骨遠位端骨折は臨床の現場で度々遭遇する外傷で ある。掌側ロッキングプレートによる内固定術は一般 的な治療法となっているが，手指の屈筋腱断裂のリス クが潜んでおり, ADL を損なう重大な合併症となる. Soong らは $4.3 \%$ の症例に手指屈筋腱断裂が起きると 報告しており ${ }^{6)}$ ，現在まで諸家より数論の症例報告が されている。今回, 我々は橈骨遠位端骨折掌側ロッキ ングプレート術後に長母指屈筋腱（以下 FPL）断裂 を来した 3 症例を経験し，FPL 断裂の原因とその再 建方法を検討した。

\section{対象・方法}

対象は 2002 年から 2013 年, 当科及び関連病院にて 橈骨遠位端骨折に対して掌側ロッキングプレート固定 術後の FPL 断裂に対し再建を施行した 3 例（女性 2 例, 男性 1 例）である。再建時の平均年齢は 69.7 (52-81) 歳であった. 使用プレートは全例 Acumed 社の Acu-Loc ${ }^{\circledR}$ あり，プレート固定から FPL 断裂 までの平均期間は 17.7 (5-37) カ月であった. プレー 卜の固定位置は, 2 例が Soong らの分類で Grade 1, 1 例が Grade 2 であった. Soong らの分類とは, プレー
卜固定後の単純 X 線側面像にて，橈骨掌側縁より橈 骨骨軸に平行な直線を引き，その線より背側にプレー トが収まっていれば Grade 0, 線より掌側に突出して いれば Grade 1, 橈骨掌側縁をプレートが覆っていれ ば Grade 2 としている. Soong らの報告では, Grade 0 で屈筋腱断裂率は 0\%, Grade 1 で 1.9\%, Grade 2 で $4.3 \%$ である ${ }^{6}$ (図 1).

FPL 断裂から 16 日で再建可能であった 1 例のみ長 掌筋腱（以下 PL）による腱移植術にて再建し，断裂 から再建まで数力月を要した 2 例は環指浅指屈筋腱 (以下 FDS) の腱移行術にて再建した。再建後の母指 IP • MP 関節の可動域, 直近の Quick DASH Score を 評価し検討した（表 1$)$.

\section{結果}

腱移植術を施行した 1 例の術後 Quick DASH Score は 17.5 であり，可動域はほぼ健側と同等まで改善し た。腱移行術を施行した 2 例の Quick DASH score は それぞれ 32.5 と 65.9 であり，2 例とも母指の可動域 制限を認めた。腱移植術を施行した例でより良好な術 後成績を得た（表 2).

\footnotetext{
* 山口大学大学院医学系研究科整形外科学

** 宇部興産中央病院
} 

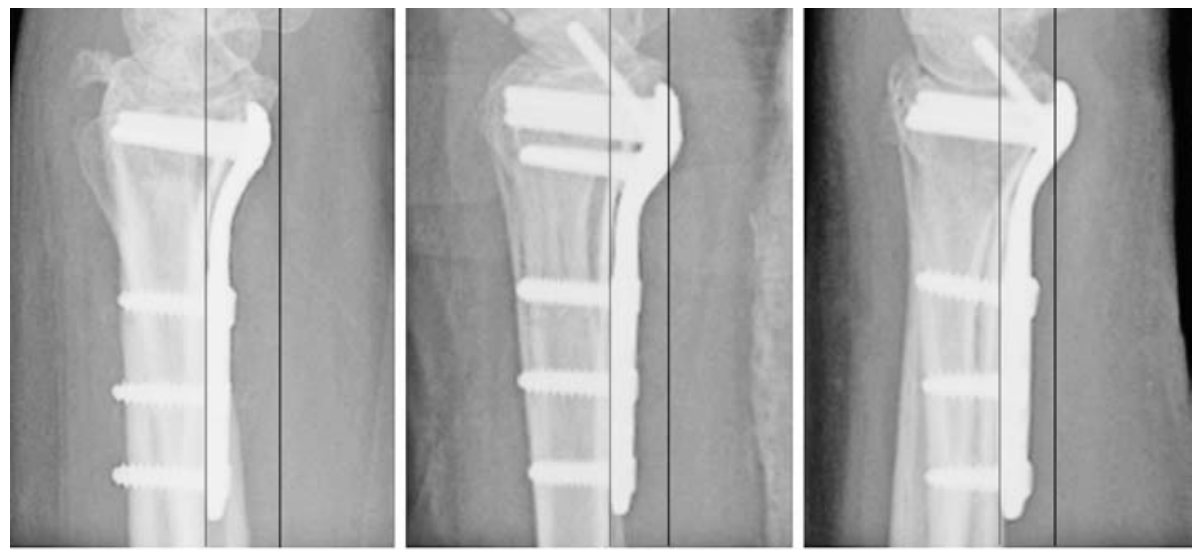

図 1 Soong らの分類. 橈骨骨軸に平行な直線. 左よりそれぞれ Grade 0, Grade 1, Grade 2.

表 1 対象

\begin{tabular}{c||c|c|c|c|c|c}
\hline \hline \multirow{2}{*}{ 患者番号 } & 年齢/性別 & 使用プレート & Soong らの分類 & $\begin{array}{c}\text { プレート固定〜 } \\
\text { 断裂期間 }\end{array}$ & 断裂〜再建期間 & 再建法 \\
\hline \hline 1 & $76 / \mathrm{F}$ & Acu-Loc ${ }^{\circledR}$ & Grade 2 & 11 カ月 & 4 カ月 & 環指 FDS 移行術 \\
\hline 2 & $81 / \mathrm{F}$ & Acu-Loc ${ }^{\circledR}$ & Grade 1 & 5 カ月 & 6 カ月 & 環指 FDS 移行術 \\
\hline 3 & $52 / \mathrm{M}$ & Acu-Loc & Grade 1 & 37 カ月 & 16 日 & PL 移植術
\end{tabular}

表 2 結果

\begin{tabular}{|c|c|c|}
\hline 再建方法 & 再建後母指可動域 & Quick DASH Score \\
\hline \multirow{2}{*}{$\begin{array}{l}\text { 環指 FDS } \\
\text { 移行術 }\end{array}$} & $\begin{array}{cc}\operatorname{IP} \text { 伸展 } 0^{\circ} & \text { 屈曲 } 30^{\circ} \\
\mathrm{MP} \text { 伸展 } 0^{\circ} & \text { 屈曲 } 50^{\circ}\end{array}$ & 32.5 \\
\hline & 屈曲拘縮著明に残存 & 65.9 \\
\hline PL 移植術 & $\begin{array}{l}\mathrm{IP} \text { 伸展 } 0^{\circ} \text { 屈曲 } 80^{\circ} \\
\operatorname{MP} \text { 伸展 } 20^{\circ} \text { 屈曲 } 50^{\circ}\end{array}$ & 17.5 \\
\hline
\end{tabular}

\section{症 例 1}

52 歳男性，右利き。2010 年 12 月に左橈骨遠位端骨 折を受傷し，近医にて Acu-Loc ${ }^{\circledR}$ を用いて骨接合術が 施行された。以後，症状なく経過したが，2013 年 1 月，仕事中に左母指 IP 関節が屈曲不可能となり当院 を受診した。

初診時の単純 X 線でプレート固定位置はSoong ら の分類で Grade 1 であった. FPL 断裂と診断し, 症 状出現から 16 日後にPLによる腱移植術とプレート の抜釘術を施行した.FPLはプレートの遠位端直上 で断裂しており，術中母指 IP 関節が屈曲 $10^{\circ}$ 程度で 交叉縫合した。術後一 $30^{\circ}$ 程度の伸展制限を認め, 縫
合腱の癒着と判断し腱剥離術を施行した。術後 3 力月 で母指 IP 関節伸展 $0^{\circ}$, 屈曲 $80^{\circ}, \mathrm{MP}$ 関節伸展 $20^{\circ}$, 屈曲 $50^{\circ}$ とほほ健側と同等な可動域を認め, Quick DASH Score は 17.5 と良好な成績であった（図 2).

\section{症例 2}

76 歳女性，右利き。2007 年 2 月に右橈骨遠位端骨 折を受傷し，当院にて Acu-Loc ${ }^{\circledR}$ を用いて骨接合術を 施行した. 2010 年 1 月より右母指 IP 関節の屈曲不可 能を自覚していたが病院受診なく，同年 4 月の定期受 診の際に，FPL断裂と診断された。

診断時, 単純 X 線でプレート固定位置はSoong ら の分類で Grade 2 であった. 症状出現から 4 カ月後に 環指 FDSの腱移行術とプレートの抜釷術を施行した。 術後約 3 年で母指 IP 関節伸展 $0^{\circ}$, 屈曲 $30^{\circ}, \mathrm{MP}$ 関節 伸展 $0^{\circ}$, 屈曲 $50^{\circ}$ と IP 関節の屈曲制限を認めた。 母指 IP 関節の屈曲は環指と同時に屈曲すれば可能であっ た. Quick DASH Scoreは32.5であった（図3).

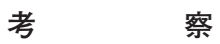

橈骨遠位端骨折掌側ロッキングプレート固定術後の 


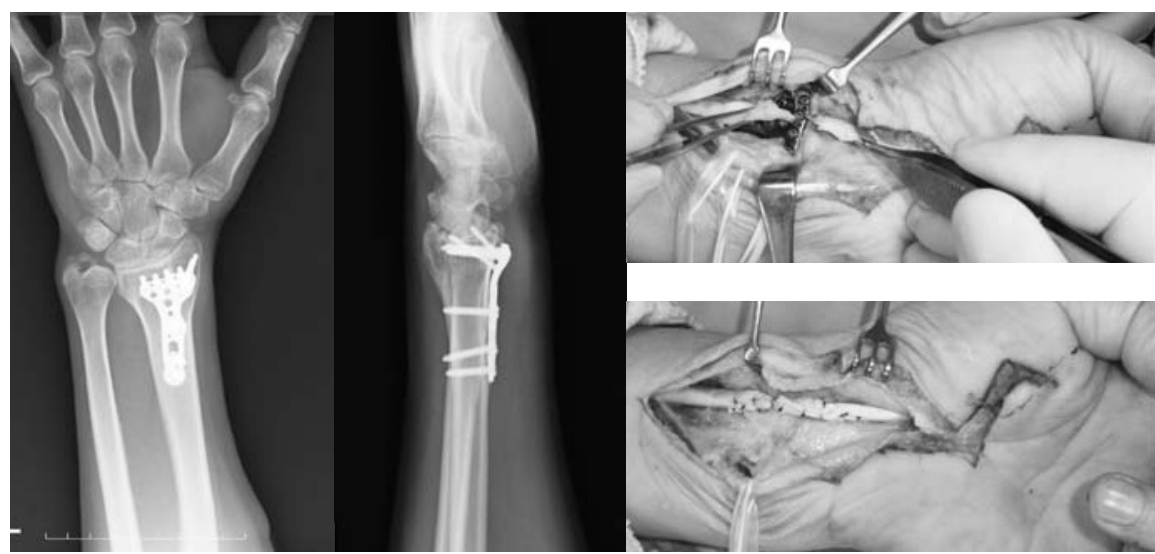

図2 (左) 単純 X 線像

プレートが橈骨掌側端より掌側に突出しており, Soong らの分類で Grade 1.

(右上) 術中写真

プレート遠位端直上で FPL 断裂

（右下）術中写真

交叉縫合にて縫合した。

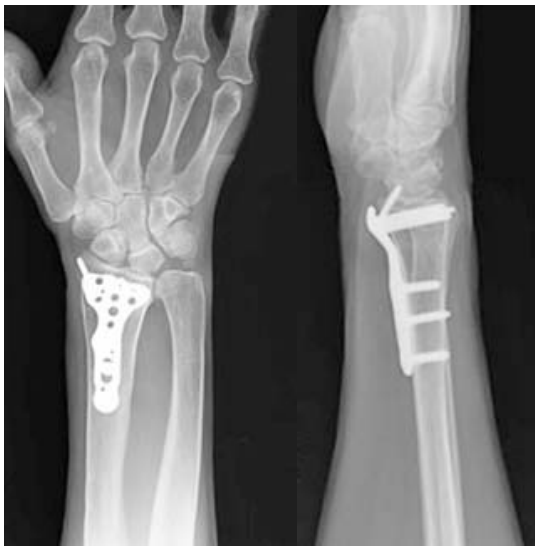

図 3 単純 $X$ 線像

プレートが橈骨掌側縁を覆うように固定され

て抢り, Soong らの分類で Grade 2.

合併症として，FPL 断裂は諸家より報告されており， その原因について議論されている。

Orbay らが提唱したWatershed line は，屈筋腱群 が最も橈骨と近接する部位であり，それより遠位でプ レートが固定されると, プレートと屈筋腱群の干渉に より腱断裂のリスクが上昇する ${ }^{5)}$. Soong らの分類に よると，プレートの設置位置がWatershed lineより 遠位でなくても，橈骨掌側縁よりも掌側に突出してい れば，腱断裂のリスクが上昇する ${ }^{1)}$. 全例 Soong らの
分類で Grade 1 以上であり，腱断裂のリスクを有して いた．プレートは近位設置を基本とし，やむを得ず遠 位設置となる場合は，より薄いプレートが選択される ベきである。プレート固定位置にて腱断裂のリスク ファクターのある症例は，プレートの早期抜去が考慮 されるべきである。

腱断裂後の再建法に関しては，PL腱の腱移植ある いは端々縫合によるオリジナル腱の再建，または環指 FDSを用いた腱移行術が一般的である。現在，その 術後成績を比較した研究はない。諸家の報告では腱移 植術・端々縫合でのオリジナル腱を再建した症例の方 が良好な成績を示しており ${ }^{1-4) 7)}$ (表 3), 今回の症例の 結果と一致していた。腱断裂は早期に診断し，腱移植 術にて再建することが望ましいと考えられた。

\section{参 考 文 献}

1) Cho, C. H., et al.: Delayed rupture of flexor pollicis longus after volar plating for distal radius fracture. Clin. Orthop. Surg., 4 : 325-328, 2012.

2) Duncan, S. F., Weiland, A.J.: Delayed rupture of the flexor pollicis longus tendon after routine volar placement of a T-plate on the distal radius. Am. J. Orthop., 36 (12) : 669-670, 2007.

3) Koo, S. C., Ho, S.T.: Delayed rupture of flexor pollicis longus tendon after volar plating of the distal radius. 
表 3 諸家の FPL 腱断裂後の再建法と成績

\begin{tabular}{|c|c|c|c|c|}
\hline 著者 & 年齢/性別 & 断裂～再建期間 & 再建方法 & 再建後 IP 関節 ROM \\
\hline Duncan & 70 代後半/女 & 3 力月 & $\begin{array}{c}\text { 環指 FDS 腱 } \\
\text { 腱移行術 }\end{array}$ & 伸展 $0^{\circ}$ 屈曲 $10^{\circ}$ \\
\hline Koo & 63/女 & 数力月 & PL 腱移植術 & 可動域改善 \\
\hline \multirow[t]{3}{*}{ Valbuena } & 62/男 & 不明 & PL 腱移植術 & 伸展 $0^{\circ}$ 屈曲 $70^{\circ}$ \\
\hline & 42/男 & 不明 & PL 腱移植術 & 伸展 $30^{\circ}$ 屈曲 $90^{\circ}$ \\
\hline & 60/男 & 24 力月 & 断端縫合 & 完全可動域 \\
\hline Cho & 63/女 & 10 日間 & 断端綘合 & 完全可動域 \\
\hline Nunley & 72/女 & 6 力月 & $\begin{array}{c}\text { 環指 FDS 腱 } \\
\text { 腱移行術 }\end{array}$ & 伸展 $0^{\circ}$ 屈曲 $60^{\circ}$ \\
\hline
\end{tabular}

Hand Surg., $11: 67-70,2006$

4) Nunley, J. A., Rowan, R. R.: Delayed rupture of the flexor pollicis longus tendon after inappropriate placement of the $\pi$ plate on the volar sruface of the distal radius. J. Hand Surg., 24 A : 1279-1280, 1999.

5) Orbay, J.: Volar plate fixation of distal radius fractures. Hand Clin., 21:347-354, 2005.

6) Soong, M., et al.: Volar locking plate implant promi- nence and flexor tendon rupture. J. Bone Joint Surg. Am., $93: 328-335,2011$.

7) Valbuena, S. E., et al. : Rupture of flexor tendon following volar plate of distal radius fracture. Report of five cases. Chir. Main, 29: 109-113, 2010. 